\title{
Calibration of mass transfer-based models to predict reference crop evapotranspiration
}

\author{
Mohammad Valipour
}

Received: 15 November 2014 / Accepted: 19 February 2015/Published online: 5 March 2015

(C) The Author(s) 2015. This article is published with open access at Springerlink.com

\begin{abstract}
The present study aims to compare mass transfer-based models to determine the best model under different weather conditions. The results showed that the Penman model estimates reference crop evapotranspiration better than other models in most provinces of Iran (15 provinces). However, the values of $R^{2}$ were less than 0.90 for 24 provinces of Iran. Therefore, the models were calibrated, and precision of estimation was increased (the values of $R^{2}$ were less than 0.90 for only ten provinces in the modified models). The mass transfer-based models estimated reference crop evapotranspiration in the northern (near the Caspian Sea) and southern (near the Persian Gulf) Iran (annual relative humidity more than $65 \%$ ) better than other provinces. The best values of $R^{2}$ were 0.96 and 0.98 for the Trabert and Rohwer models in Ardabil (AR) and Mazandaran (MZ) provinces before and after calibration, respectively. Finally, a list of the best performances of each model was presented to use other regions and next studies according to values of mean, maximum, and minimum temperature, relative humidity, and wind speed. The best weather conditions to use mass transfer-based equations are $8-18{ }^{\circ} \mathrm{C}$ (with the exception of Ivanov), $<25.5^{\circ} \mathrm{C},<15^{\circ} \mathrm{C}$, $>55 \%$ for mean, maximum, and minimum temperature, and relative humidity, respectively.
\end{abstract}

Keywords Calibration - Evapotranspiration · FAO Penman-Monteith · Humidity · Iran

M. Valipour $(\square)$

Young Researchers and Elite Club, Kermanshah Branch, Islamic Azad University, Kermanshah, Iran

e-mail: vali-pour@hotmail.com

\section{Introduction}

The maximum precision of actual evapotranspiration could be obtained using lysimeter (Xu and Chen 2005; Valipour 2012a, b; Valipour 2015b, c) or imaging techniques (Hart et al. 2009) that their costs are too high. Thus, the FAO Penman-Monteith model (Allen et al. 1998) has been replaced to estimate reference crop evapotranspiration. Although the FAO Penman-Monteith (FPM) has been applied in various regions of the world (Rahimi et al. 2015; Valipour 2014m, n, o; Valipour and Eslamian 2014), but it needs too many parameters to estimate reference crop evapotranspiration. In the most regions, as weather data are limited, it is not possible to use the FPM. Therefore, empirical methods including mass transfer-, radiation-, temperature-, and pan evaporation-based methods have been developed for estimation of the reference crop evapotranspiration using limited data. The mass transfer-based model is one of the most widely used models for estimating reference crop evapotranspiration. Valipour (2014p, q, r, s, t) studied estimation of evapotranspiration in Iran. The results showed that each province of Iran needs to a specified evapotranspiration equation, if the highest accuracy is desirable. Further examination of the performance resulted in the following rank of precision as compared with the FPM estimates: Priestley-Taylor, Makkink, Hargreaves, Blaney-Criddle, and Rohwer ( $\mathrm{Xu}$ and Singh 2002). Adjusted Dalton model gives the better estimation of reference crop evapotranspiration compared with adjusted Penman-Monteith model for the Kendall subwatershed (Rim 2000). The top six ranked methods obtained for the average as well as for central Saudi Arabia ratings are ranked in the following order of merit: Jensen-Haise, class A pan, Ivanov, adjusted class A pan, Behnke-Maxey, and Stephens-Stewart (Al-Sha'lan and Salih 1987). Azhar 
and Perera (2011) calibrated the Meyer model as well as nine other (temperature and radiation-based) models under Southeast Australian Conditions successfully. Zhai et al. (2010) calibrated the Hargreaves, Makkink, Turc, Priestley-Taylor, Jensen-Haise, Doorenbos-Pruitt, Abtew, McGuinness-Bordne, Rohwer, and Blaney-Criddle. It can be concluded that calibration can be used to modify reference crop evapotranspiration equations with multi-station data to improve the precision of reference crop evapotranspiration estimates in northwest China. Singh and $\mathrm{Xu}$ (1997) evaluated the Meyer, Dalton, and Rohwer for determining free water evaporation at four climatological stations in north-western Ontario, Canada. The results of comparison showed that all equations were in reasonable agreement with observed evaporation. More accurate estimation of potential evapotranspiration can help other studies including surface and pressurized irrigation water management (Mahdizadeh Khasraghi et al. 2014; Valipour 2012c, e, f, g, h, 2013a, b, c, d, 2014a, b, c, d, e, f, g, h, i, j, k, 1, y, 2015a, b; Valipour and Montazar 2012a, b, c), drainage engineering (Valipour 2012i, j, 2013g, h, 2014v, w), environmental studies (Valipour 2012d, 2013a, b, 2014x), and water resources management (Banihabib et al. 2012; Valipour 2012a, b, c, d, 2013c, e, f, 2014u, 2015a). In the previous studies, one or more of the mass transferbased models are compared with temperature, radiation, or pan evaporation-based models. In other cases, there are some models which can estimate reference crop evapotranspiration better than the mass transfer-based models. This is because the previous studies focus on specific weather conditions (not suitable for applying the mass transfer-based model) or/and do not consider mass transfer-based models. Moreover, the results of the previous studies are not useable for estimating reference crop evapotranspiration in other regions, because they are recommended for one or more climatic conditions. However, a climatic condition contains various value of weather parameters (e.g., temperature, relative humidity, wind speed, solar radiation, etc.), and results of each research (for a region with specific weather variations) are not applicable for other regions without determining specified ranges of each weather parameter even if climatic conditions (e.g., humid, arid, semi-arid, temperate, etc.) are the same for both regions. In addition, the governments cannot schedule for irrigation and agricultural water management when reference crop evapotranspiration is estimated for a basin, wetland, watershed, or catchment instead a state or province (different parts of them are located at more than one state or province) and/or number of weather station used is low (increasing uncertainty). Therefore, this study aims to estimate reference crop evapotranspiration for 31 provinces of Iran (considering their usability for longterm and macroeconomic policies of governments and adaptability to various weather conditions) using average data of 181 synoptic station (decreasing uncertainty) and by 11 mass transfer-based models to determine the best model based on the weather conditions of each province (for which the best weather parameters are determined to use other regions and next researches) as well as increasing precision of the models by calibration of them for each province.

\section{Materials and methods}

In this study, weather information (from 1951 to 2010) is gathered from 181 synoptic stations of 31 provinces in Iran. Table 1 shows the number of years that data were

Table 1 Position of all provinces and synoptic stations

\begin{tabular}{|c|c|c|c|c|}
\hline Province & Latitude $(\mathrm{N})$ & Longitude (E) & $\begin{array}{l}\text { Recorded } \\
\text { length (year) }\end{array}$ & $\begin{array}{l}\text { No. of } \\
\text { station }\end{array}$ \\
\hline $\mathrm{AL}$ & $35^{\circ} 55^{\prime}$ & $50^{\circ} 54^{\prime}$ & 20 & 1 \\
\hline $\mathrm{AR}$ & $38^{\circ} 15^{\prime}$ & $48^{\circ} 17^{\prime}$ & 30 & 4 \\
\hline BU & $28^{\circ} 59^{\prime}$ & $50^{\circ} 50^{\prime}$ & 55 & 5 \\
\hline $\mathrm{CB}$ & $32^{\circ} 17^{\prime}$ & $50^{\circ} 51^{\prime}$ & 51 & 4 \\
\hline EA & $38^{\circ} 05^{\prime}$ & $46^{\circ} 17^{\prime}$ & 55 & 10 \\
\hline ES & $32^{\circ} 37^{\prime}$ & $51^{\circ} 40^{\prime}$ & 55 & 12 \\
\hline FA & $29^{\circ} 32^{\prime}$ & $52^{\circ} 36^{\prime}$ & 55 & 9 \\
\hline $\mathrm{GH}$ & $36^{\circ} 15^{\prime}$ & $50^{\circ} 03^{\prime}$ & 47 & 2 \\
\hline GI & $37^{\circ} 15^{\prime}$ & $49^{\circ} 36^{\prime}$ & 50 & 4 \\
\hline GO & $36^{\circ} 51^{\prime}$ & $54^{\circ} 16^{\prime}$ & 54 & 3 \\
\hline HA & $34^{\circ} 52^{\prime}$ & $48^{\circ} 32^{\prime}$ & 55 & 4 \\
\hline $\mathrm{HO}$ & $27^{\circ} 13^{\prime}$ & $56^{\circ} 22^{\prime}$ & 49 & 9 \\
\hline IL & $33^{\circ} 38^{\prime}$ & $46^{\circ} 26^{\prime}$ & 20 & 3 \\
\hline $\mathrm{KB}$ & $30^{\circ} 50^{\prime}$ & $51^{\circ} 41^{\prime}$ & 19 & 1 \\
\hline $\mathrm{KE}$ & $30^{\circ} 15^{\prime}$ & $56^{\circ} 58^{\prime}$ & 55 & 8 \\
\hline $\mathrm{KH}$ & $31^{\circ} 20^{\prime}$ & $48^{\circ} 40^{\prime}$ & 55 & 14 \\
\hline $\mathrm{KO}$ & $35^{\circ} 20^{\prime}$ & $47^{\circ} 00^{\prime}$ & 47 & 7 \\
\hline $\mathrm{KS}$ & $34^{\circ} 21^{\prime}$ & $47^{\circ} 09^{\prime}$ & 55 & 6 \\
\hline LO & $33^{\circ} 26^{\prime}$ & $48^{\circ} 17^{\prime}$ & 55 & 9 \\
\hline MA & $34^{\circ} 06^{\prime}$ & $49^{\circ} 46^{\prime}$ & 51 & 4 \\
\hline $\mathrm{MZ}$ & $36^{\circ} 33^{\prime}$ & $53^{\circ} 00^{\prime}$ & 55 & 7 \\
\hline NK & $37^{\circ} 28^{\prime}$ & $57^{\circ} 16^{\prime}$ & 24 & 1 \\
\hline QO & $34^{\circ} 42^{\prime}$ & $50^{\circ} 51^{\prime}$ & 20 & 1 \\
\hline RK & $36^{\circ} 16^{\prime}$ & $59^{\circ} 38^{\prime}$ & 55 & 12 \\
\hline SB & $29^{\circ} 28^{\prime}$ & $60^{\circ} 05^{\prime}$ & 55 & 8 \\
\hline SE & $35^{\circ} 35^{\prime}$ & $53^{\circ} 33^{\prime}$ & 55 & 4 \\
\hline SK & $32^{\circ} 52^{\prime}$ & $59^{\circ} 12^{\prime}$ & 51 & 3 \\
\hline $\mathrm{TE}$ & $35^{\circ} 41^{\prime}$ & $51^{\circ} 19^{\prime}$ & 55 & 8 \\
\hline WA & $37^{\circ} 32^{\prime}$ & $45^{\circ} 05^{\prime}$ & 55 & 8 \\
\hline YA & $31^{\circ} 54^{\prime}$ & $54^{\circ} 17^{\prime}$ & 54 & 6 \\
\hline $\mathrm{ZA}$ & $36^{\circ} 41^{\prime}$ & $48^{\circ} 29^{\prime}$ & 51 & 4 \\
\hline
\end{tabular}


measured and number of stations along with latitude and longitude.

In each station, average weather data in years measured are considered as value of that weather parameter in each month (e.g., value of relative humidity in July for NK is average of 24 data gathered). A spatial interpolation method is usually used to obtain an averaged value from stations. However, the most of synoptic stations have been distributed in north, south, west, and east of each province based on different weather conditions and considering equal spatial distances to skip spatial interpolation method. Therefore, average of data in all stations has been considered as value of that weather parameter in each month for provinces with more than one station (e.g., value of relative humidity in July for $\mathrm{KH}$ is average of $55 \times 14=770$ data gathered). All of the data mentioned were used for estimating reference crop evapotranspiration using 11 mass transfer-based models and compared with FAO PenmanMonteith (FPM) model to determine the best model based on the weather conditions of each province (Table 2).

The parameters of each model indicate that each model apply how many parameters to estimate evapotranspiration. In addition, in some synoptic stations, there is no access to all of them; therefore, the researchers can select the best model based on available data and error of each model. The best model for each province and the best performance of each model were determined using the coefficient of determination [Eq. (1)] and mean bias error [Eq. (2)]:

$$
R^{2}=1-\sum\left(\mathrm{ET}_{\mathrm{FPM}_{i}}-\mathrm{ET}_{\mathrm{m}_{i}}\right)^{2} / \sum\left(\mathrm{ET}_{\mathrm{FPM}_{\mathrm{i}}}-\frac{\sum \mathrm{ET}_{\mathrm{FPM}_{\mathrm{i}}}}{12}\right)^{2}
$$

$\mathrm{MBE}=\left(\sum \mathrm{ET}_{\mathrm{FPM}_{\mathrm{i}}}-\mathrm{ET}_{\mathrm{m}_{i}}\right) / 12$

In which, $i$ indicates month, $\mathrm{ET}_{\mathrm{FPM}}$ indicates reference crop evapotranspiration calculated for FAO PenmanMonteith (FPM) model, $\mathrm{ET}_{\mathrm{m}}$ indicates reference crop evapotranspiration calculated for mass transfer-based models, and MBE is mean bias error (MBE). These formulae were selected due to wide use in previous works as well as their capability to compare with other studies. The best model for each province was modified to increase precision of estimating by calibration of the coefficients (Table 2) similar to the studies of Irmak et al. (2003) and Xu and Singh (2000) and using multiplication linear regressions in which the FPM values were used as the dependent variable, and other parameters (Table 2) were the independent variables. In each province, twothird of the data were used for development of the equations and one-third of the data were applied for validation. This partitioning is due to need to more data for training the models based on previous works (e.g., $\mathrm{Xu}$ and Singh 2000). Then, reference crop evapotranspiration calculated using new formulas was compared with FPM, and variations of the errors were investigated. Finally, map of annual average of solar radiation, mean, maximum, and minimum temperature, relative humidity, and wind speed was provided, and the best performance of each model based on these values was determined. Meanwhile, the map of the best model for each province and the map of the error calculated for each province have been presented.

Table 2 Model used and parameters applied in each model

\begin{tabular}{|c|c|c|c|}
\hline Model & References & Formula & Parameters \\
\hline FAO Penman-Monteith & Allen et al. (1998) & $\mathrm{ET}_{o}=\frac{0.408\left(R_{n}-G\right)+\gamma_{\frac{900}{T+273}} u\left(e_{s}-e_{a}\right)}{\Delta+\gamma(1+0.34 u)}$ & $H, \varphi, T, T_{\min }, T_{\max }, \mathrm{RH}, u, n$ \\
\hline Albrecht & Albrecht (1950) & $\mathrm{ET}_{o}=(1.005+2.97 u)\left(e_{s}-e_{a}\right)$ & $T, T_{\min }, T_{\max }, \mathrm{RH}, u$ \\
\hline Brockamp-Wenner & Brockamp and Wenner (1963) & $\mathrm{ET}_{o}=5.43 u^{0.456}\left(e_{s}-e_{a}\right)$ & $T, T_{\min }, T_{\max }, \mathrm{RH}, u$ \\
\hline Dalton & Dalton (1802) & $\mathrm{ET}_{o}=(3.648+0.722 u)\left(e_{s}-e_{a}\right)$ & $T, T_{\min }, T_{\max }, \mathrm{RH}, u$ \\
\hline Ivanov & Romanenko (1961) & $\mathrm{ET}_{o}=0.00006(25+T)^{2}(100-\mathrm{RH})$ & $T, \mathrm{RH}$ \\
\hline Mahringer & Mahringer (1970) & $\mathrm{ET}_{o}=2.86 u^{0.5}\left(e_{s}-e_{a}\right)$ & $T, T_{\min }, T_{\max }, \mathrm{RH}, u$ \\
\hline Meyer & Meyer (1926) & $\mathrm{ET}_{o}=(3.75+0.503 u)\left(\mathrm{e}_{s}-e_{a}\right)$ & $T, T_{\min }, T_{\max }, \mathrm{RH}, u$ \\
\hline Papadakis & Papadakis (1966) & $\mathrm{ET}_{o}=2.5\left(e_{\mathrm{ma}}-e_{a}\right)$ & $T_{\min }, T_{\max }, \mathrm{RH}$ \\
\hline Penman & Penman (1948) & $\mathrm{ET}_{o}=(2.625+0.000479 / u)\left(\mathrm{e}_{s}-e_{a}\right)$ & $T, T_{\min }, T_{\max }, \mathrm{RH}, u$ \\
\hline Rohwer & Rohwer (1931) & $\mathrm{ET}_{o}=(3.3+0.891 u)\left(e_{s}-e_{a}\right)$ & $T, T_{\min }, T_{\max }, \mathrm{RH}, u$ \\
\hline Trabert & Trabert (1896) & $\mathrm{ET}_{o}=3.075 u^{0.5}\left(e_{s}-e_{a}\right)$ & $T, T_{\min }, T_{\max }, \mathrm{RH}, u$ \\
\hline WMO & WMO (1966) & $\mathrm{ET}_{o}=(1.298+0.934 u)\left(e_{s}-e_{a}\right)$ & $T, T_{\min }, T_{\max }, \mathrm{RH}, u$ \\
\hline
\end{tabular}

$E T_{o}$ reference crop evapotranspiration $\left(\mathrm{mm} \mathrm{day}^{-1}\right), R_{n}$ net radiation $\left(\mathrm{MJ} \mathrm{m}{ }^{-2}\right.$ day $\left.^{-1}\right), G$ soil heat flux $\left(\mathrm{MJ} \mathrm{m}^{-2}\right.$ day $\left.^{-1}\right), \gamma$ psychrometric constant $^{-}$ $\left(\mathrm{kPa} /{ }^{\circ} \mathrm{C}\right), e_{s}$ saturation vapor pressure $(\mathrm{kPa}), e_{a}$ actual vapor pressure $(\mathrm{kPa}), \Delta$ slope of the saturation vapor pressure-temperature curve $(\mathrm{kPa} /$

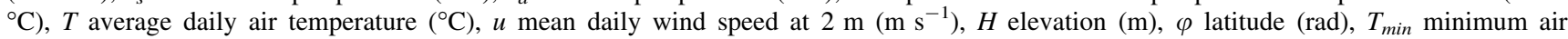
temperature $\left({ }^{\circ} \mathrm{C}\right), T_{\max }$ maximum air temperature $\left({ }^{\circ} \mathrm{C}\right), R H$ average relative humidity $(\%), n$ actual duration of sunshine (hr), $R_{s}$ solar radiation $\left(\mathrm{MJ} \mathrm{m}^{-2} \mathrm{day}^{-1}\right), e_{m a}$ saturation vapor pressure at the monthly mean daily maximum temperature 


\section{Results and discussion}

Estimating reference crop evapotranspiration for the 31 provinces of Iran

Table 3 and Eq. (2) indicate that in all models (in the most cases), the estimations are more than reference crop evapotranspiration calculated using the FPM, except the Penman. The Albrecht model provided the greatest overestimate $17.7 \mathrm{~mm}$ day $^{-1}$, while the Papadakis and Penamn models yielded the least overestimate $0.03 \mathrm{~mm}_{\text {day }}{ }^{-1}$ both for AR and QO, respectively (Table 3). This underlines that

Table 3 Average error of the model used for all provinces

\begin{tabular}{llr}
\hline Model & Evaluation index & Average of all provinces \\
\hline Al. & MBE & -6.29 \\
& $R^{2}$ & 0.71 \\
BW & MBE & -6.05 \\
& $R^{2}$ & 0.69 \\
Da. & MBE & -2.82 \\
& $R^{2}$ & 0.73 \\
Iv. & MBE & -1.80 \\
& $R^{2}$ & 0.38 \\
Ma. & MBE & -1.54 \\
& $R^{2}$ & 0.45 \\
Me. & MBE & -2.28 \\
& $R^{2}$ & 0.70 \\
Pa. & MBE & -2.05 \\
& $R^{2}$ & 0.78 \\
Pe. & MBE & 0.65 \\
& $R^{2}$ & 0.83 \\
Ro. & MBE & -2.89 \\
Tr. & $R^{2}$ & 0.49 \\
WMO & MBE & -1.95 \\
& $R^{2}$ & 0.79 \\
\hline & MBE & -0.51 \\
& $R^{2}$ & 0.39 \\
\hline
\end{tabular}

The underlines show the best value of each method, and the bolds show the best value of each province

Al. Albrecht, $B W$ Brockamp-Wenner, Da. Dalton, Iv. Ivanov, Ma. Mahringer, $\mathrm{Me}$. Meyer, $\mathrm{Pa}$. Papadakis, Pe. Penman, Ro. Rohwer, Tr. Trabert mass transfer-based models should be used carefully in accordance with weather conditions of each province. Because according to the $R^{2}$ values, each model estimates reference crop evapotranspiration for only one or few provinces as acceptable. In the other words, precision of estimating by mass transfer-based models is very sensitive to variations of the parameters used in each model (Table 2).

\section{Comparison of the best models for each province}

Figure 1 compares reference crop evapotranspiration using FPM with values estimated using the best method (based on Table 3) for each province.

The Trabert for $\mathrm{AR}\left(R^{2}=0.96\right.$ and $\left.\mathrm{MBE}=-0.01\right)$, Mahringer for West Azerbaijan (WA) $\left(R^{2}=0.93\right.$ and $\mathrm{MBE}=0.20), \quad$ Brockamp-Wenner for Gilan (GI) $\left(R^{2}=0.92\right.$ and $\left.\mathrm{MBE}=-0.27\right)$, and Ivanov for Bushehr (BU) $\left(R^{2}=0.92\right.$ and $\left.\mathrm{MBE}=-0.43\right)$ yielded the best reference crop evapotranspiration as compared to that from the FPM. However, the Penman has been introduced as the best model in the most provinces (15 provinces). In general, mass transfer-based models are more suitable $\left(\mathrm{R}^{2}\right.$ more than 0.90) for East Azerbaijan (EA), WA, AR, Gorgan (GO), GI, MZ, (north of Iran), and BU (south of Iran). However, preciseness of estimating is not desirable $\left(R^{2}\right.$ less than 0.80) in Khuzestan (KH), Semnan (SE), Sistan and Baluchestan (SB), Kerman (KE), Kohkiluyeh and Boyerahmad (KB), Lorestan (LO), and Hormozgan (HO), and it is less than 0.90 for 24 provinces of Iran. These values indicate very different performance of the mass transfer-based models for a specific weather condition in each province. For instance, an impressive difference between the World Meteorological Organization (WMO) and Brockamp-Wenner models is observable in comparison Zanjan (ZA), Ghazvin (GH), and Hamedan (HA) (the Brockamp-Wenner is the worst model and the WMO is the best model) with GI (the WMO is the worst model and the Brockamp-Wenner is the best model). However, according to Table 2, the Ivanov model is a function of mean temperature and relative humidity, the Papadakis is a function of minimum and maximum temperature and relative humidity, and the other models are a function of mean, minimum, and maximum temperature, relative humidity,
Fig. 1 Comparison of evapotranspiration $\left(\mathrm{mm} \mathrm{day}^{-1}\right)$ calculated using FAO PenmanMontieth $(F P M)$ with the best model for the best (AR) and the worst $(\mathrm{KB})$ accuracy
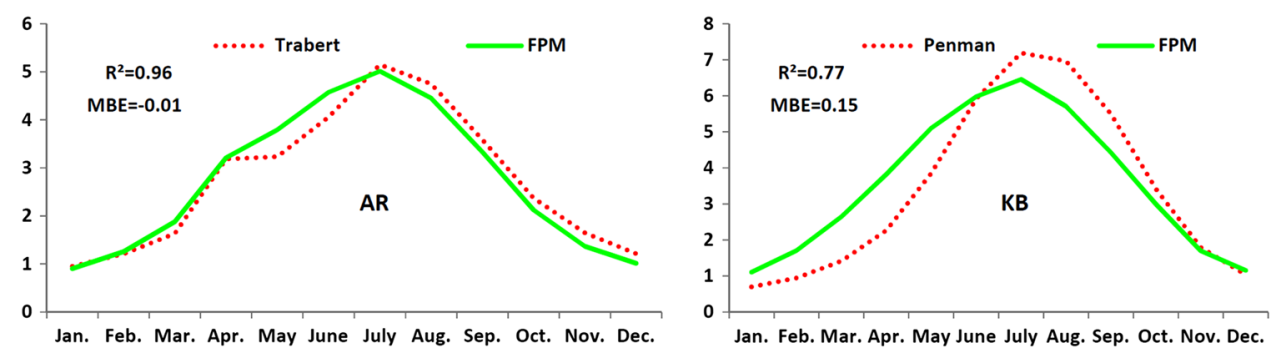
and wind speed. In addition, the only difference among the Albrecht, Dalton, Meyer, Rohwer, and WMO models is coefficients used in each model (Table 2) as well as the only difference among the Brockamp-Wenner, Mahringer, and Trabert models is also coefficients used in each model (Table 2). Thus, the coefficients of the mass transfer-based models need to be adjusted based on weather conditions of each province.

Calibration of the best models based on their coefficients

The best models for each province (Table 2 and Fig. 1) are calibrated similar to the studies of Irmak et al. (2003) and
$\mathrm{Xu}$ and Singh (2000). Table 4 shows the new formulas with the coefficients calibrated for each province.

According to Table 4, all models calibrated estimate reference crop evapotranspiration less than the FPM (with the exception of the Ivanov and Rohwer for BU and MZ, respectively). Figure 2 compares reference crop evapotranspiration using the FPM with values estimated using the models calibrated (based on Table 4) for each province.

According to Figs. 1 and 2, preciseness of the models calibrated has been increased in all provinces. The $R^{2}$ values are less than 0.90 for ten provinces [Esfahan (ES), Ilam (IL), SB, Fars (FA), Qom (QO), Kordestan (KO), Kermanshah (KS), KB, LO, and Yazd (YA)]. In the

Table 4 Formula calibrated and their error for each province

\begin{tabular}{|c|c|c|c|c|}
\hline Province & Method calibrated & New formula & $R^{2}$ & MBE \\
\hline $\mathrm{CB}$ & Mahringer & $\mathrm{ET}_{o}=2.385 u^{0.955}\left(e_{s}-e_{a}\right)$ & 0.94 & 0.20 \\
\hline EA & Papadakis & $\mathrm{ET}_{o}=2.206\left(e_{\mathrm{ma}}-e_{a}\right)$ & 0.96 & 0.05 \\
\hline WA & Mahringer & $\mathrm{ET}_{o}=1.922 u^{1.536}\left(e_{s}-e_{a}\right)$ & 0.96 & 0.15 \\
\hline AR & Trabert & $\mathrm{ET}_{o}=4.027 u^{0.293}\left(e_{s}-e_{a}\right)$ & 0.96 & 0.02 \\
\hline ES & Penman & $E T_{o}=(4.313-3.510 / u)\left(e_{s}-e_{a}\right)$ & 0.87 & 0.39 \\
\hline IL & Penman & $\mathrm{ET}_{o}=(2.346+0.555 / u)\left(e_{s}-e_{a}\right)$ & 0.86 & 0.30 \\
\hline $\mathrm{BU}$ & Ivanov & $E T_{o}=0.0000556(25+T)^{2}(100-R H)$ & 0.96 & -0.04 \\
\hline TE & Penman & $E T_{o}=(5.119-6.510 / u)\left(e_{s}-e_{a}\right)$ & 0.92 & 0.38 \\
\hline $\mathrm{AL}$ & WMO & $\mathrm{ET}_{o}=(0.719+0.970 u)\left(e_{s}-e_{a}\right)$ & 0.92 & 0.22 \\
\hline SK & Penman & $\mathrm{ET}_{o}=(3.352-0.947 / u)\left(e_{s}-e_{a}\right)$ & 0.95 & 0.16 \\
\hline RK & WMO & $\mathrm{ET}_{o}=(3.231+0.00251 u)\left(e_{s}-e_{a}\right)$ & 0.93 & 0.23 \\
\hline NK & WMO & $E T_{o}=(3.074+0.215 u)\left(e_{s}-e_{a}\right)$ & 0.93 & 0.21 \\
\hline $\mathrm{KH}$ & Penman & $\mathrm{ET}_{o}=(2.559-0.876 / u)\left(e_{s}-e_{a}\right)$ & 0.91 & 0.38 \\
\hline $\mathrm{ZA}$ & WMO & $\mathrm{ET}_{o}=(1.966 u-0.440)\left(e_{s}-e_{a}\right)$ & 0.91 & 0.23 \\
\hline SE & Penman & $E T_{o}=(2.555-0.555 / u)\left(e_{s}-e_{a}\right)$ & 0.90 & 0.25 \\
\hline SB & Penman & $E T_{o}=(4.097-3.616 / u)\left(e_{s}-e_{a}\right)$ & 0.88 & 0.34 \\
\hline FA & Penman & $\mathrm{ET}_{o}=(4.315-3.948 / u)\left(e_{s}-e_{a}\right)$ & 0.84 & 0.43 \\
\hline QO & Penman & $\mathrm{ET}_{o}=(3.082-1.440 / u)\left(e_{s}-e_{a}\right)$ & 0.89 & 0.35 \\
\hline GH & WMO & $\mathrm{ET}_{o}=(1.215+0.834 u)\left(e_{s}-e_{a}\right)$ & 0.91 & 0.26 \\
\hline $\mathrm{KO}$ & Penman & $\mathrm{ET}_{o}=(5.456-5.664 / u)\left(e_{s}-e_{a}\right)$ & 0.85 & 0.39 \\
\hline $\mathrm{KE}$ & Penman & $\mathrm{ET}_{o}=(3.965-2.681 / u)\left(e_{s}-e_{a}\right)$ & 0.91 & 0.30 \\
\hline $\mathrm{KS}$ & Penman & $\mathrm{ET}_{o}=(6.436-9.027 / u)\left(e_{s}-e_{a}\right)$ & 0.85 & 0.42 \\
\hline $\mathrm{KB}$ & Penman & $\mathrm{ET}_{o}=(3.351-1.239 / u)\left(e_{s}-e_{a}\right)$ & 0.79 & 0.39 \\
\hline GO & Trabert & $\mathrm{ET}_{o}=3.097 u^{0.543}\left(e_{s}-e_{a}\right)$ & 0.94 & 0.09 \\
\hline GI & Brockamp-Wenner & $\mathrm{ET}_{o}=1.779 u^{0.835}\left(e_{s}-e_{a}\right)$ & 0.94 & 0.12 \\
\hline LO & Penman & $\mathrm{ET}_{o}=(7.236-8.377 / u)\left(\mathrm{e}_{s}-\mathrm{e}_{a}\right)$ & 0.84 & 0.45 \\
\hline $\mathrm{MZ}$ & Rohwer & $\mathrm{ET}_{o}=(4.098 u-3.227)\left(e_{s}-e_{a}\right)$ & 0.98 & -0.01 \\
\hline MA & WMO & $E T_{o}=(2.061 u-0.656)\left(e_{s}-e_{a}\right)$ & 0.90 & 0.24 \\
\hline $\mathrm{HO}$ & WMO & $\mathrm{ET}_{o}=(1.353+0.762 u)\left(e_{s}-e_{a}\right)$ & 0.95 & 0.07 \\
\hline HA & WMO & $\mathrm{ET}_{o}=(2.048 u-0.127)\left(e_{s}-e_{a}\right)$ & 0.95 & 0.16 \\
\hline YA & Penman & $\mathrm{ET}_{o}=(7.236-8.377 / u)\left(e_{s}-e_{a}\right)$ & 0.87 & 0.44 \\
\hline
\end{tabular}

$E T_{o}$ reference crop evapotranspiration $\left(\mathrm{mm} \mathrm{day}^{-1}\right), e_{s}$ saturation vapor pressure $(\mathrm{kPa}), e_{a}$ actual vapor pressure $(\mathrm{kPa}), T$ average daily air

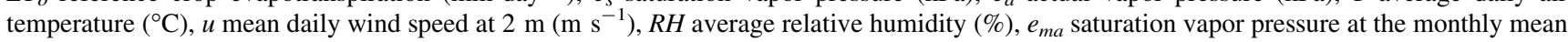
daily maximum temperature 

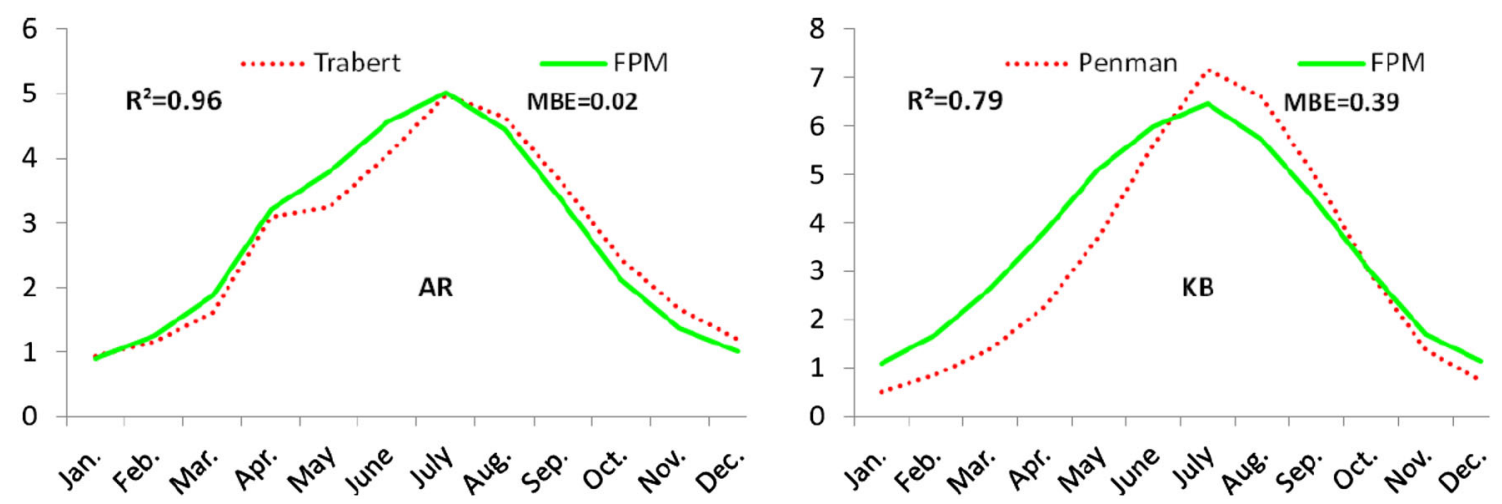

Fig. 2 Comparison of evapotranspiration $\left(\mathrm{mm} \mathrm{day}^{-1}\right)$ calculated using FAO Penman-Montieth $(F P M)$ with the best model calibrated for the best $(\mathrm{AR})$ and the worst $(\mathrm{KB})$ accuracy

Table 5 The best range to use the models based on the results of current study

\begin{tabular}{|c|c|c|c|c|c|c|c|}
\hline Model & $T$ & $T_{\max }$ & $T_{\min }$ & RH & $u$ & $R^{2}$ & MBE \\
\hline Albrecht & $14-16$ & $19.5-21.0$ & $11-13$ & $>80$ & $1.25-1.50$ & 0.86 & 0.30 \\
\hline Brockamp-Wenner & $14-16$ & $19.5-21.0$ & $11-13$ & $>80$ & $1.25-1.50$ & 0.92 & -0.27 \\
\hline Dalton & $8-10$ & $<16.5$ & $<3$ & $70-75$ & $>3.50$ & 0.94 & -0.19 \\
\hline Ivanov & $24-26$ & - & - & $65-70$ & - & 0.92 & -0.43 \\
\hline Mahringer & $8-10$ & $<16.5$ & $<3$ & $70-75$ & $>3.50$ & 0.94 & 0.19 \\
\hline Meyer & $8-10$ & $<16.5$ & $<3$ & $70-75$ & $>3.50$ & 0.94 & 0.15 \\
\hline Papadakis & - & $<16.5$ & $<3$ & $70-75$ & - & 0.94 & -0.03 \\
\hline Penman & $16-18$ & $24.0-25.5$ & $7-9$ & $35-40$ & $2.50-2.75$ & 0.87 & 0.76 \\
\hline Rohwer & $16-18$ & $21.0-22.5$ & $13-15$ & $75-80$ & $1.75-2.00$ & 0.91 & -0.13 \\
\hline Trabert & $8-10$ & $<16.5$ & $<3$ & $70-75$ & $>3.50$ & 0.96 & -0.01 \\
\hline WMO & $12-14$ & $19.5-21.0$ & $5-7$ & $55-60$ & $2.25-2.50$ & 0.88 & 0.04 \\
\hline
\end{tabular}

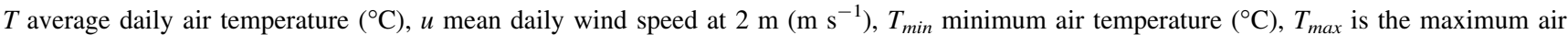
temperature $\left({ }^{\circ} \mathrm{C}\right), R H$ is the average relative humidity $(\%)$

Papadakis model (for EA), the coefficient of the model has been decreased $11.8 \%$, and $R^{2}$ has been increased $6.7 \%$. In the Mahringer model, the multiplication coefficients have been decreased 16.6 and $32.8 \%$, power coefficients have been increased 91 and $207.2 \%$, and $R^{2}$ has been increased 11.9 and $3.2 \%$ (average of $7.5 \%$ ) for CB and WA, respectively. In the Trabert model, the multiplication coefficients have been increased 31 and $0.7 \%$, power coefficients have been decreased 41.4 and $-8.6 \%$ (increasing), but $R^{2}$ has not been changed for $\mathrm{AR}$ and GO, respectively (the Trabert model does not need to calibration for its the best performance in Iran). In the Ivanov model (for BU), the multiplication coefficient has been decreased $7.3 \%$, and $R^{2}$ has been increased $4.3 \%$. In the Brockamp-Wenner model (for GI), multiplication coefficient has been decreased $67.2 \%$, power coefficient has been increased $83.1 \%$, and $R^{2}$ has been increased $2.1 \%$. Similarly, in the Rohwer, WMO, and Penman models, we can see a considerable change in the coefficients (increasing or decreasing) and $R^{2}$ (increasing) of the models after calibration (Figs. 1, 2; Tables 2, 4). Therefore, calibration is a necessary tool for modification of mass transfer-based models to increase preciseness of estimation and to adapt the best models to weather conditions (local conditions) of each province. In the models calibrated (Fig. 2), the Rohwer estimates reference crop evapotranspiration for $\mathrm{MZ}$ better than the other models.

Determining the best values of weather parameters for the best models to become applicable for next studies

According to Table 5, the best performance of the Albrecht and Brockamp-Wenner models is in similar weather conditions $\left(T=14-16{ }^{\circ} \mathrm{C}, \quad T_{\max }=19.5-21.0{ }^{\circ} \mathrm{C}, \quad T_{\min }=\right.$ $11-13{ }^{\circ} \mathrm{C}, \mathrm{RH}>80 \%$, and $\left.u=1.25-1.50 \mathrm{~m} \mathrm{~s}^{-1}\right)$. This is true for the Dalton, Mahringer, Meyer, and Trabert $(T=$ $8-10{ }^{\circ} \mathrm{C}, T_{\max }<16.5{ }^{\circ} \mathrm{C}, T_{\min }<3{ }^{\circ} \mathrm{C}, \mathrm{RH}=70-75 \%$, 

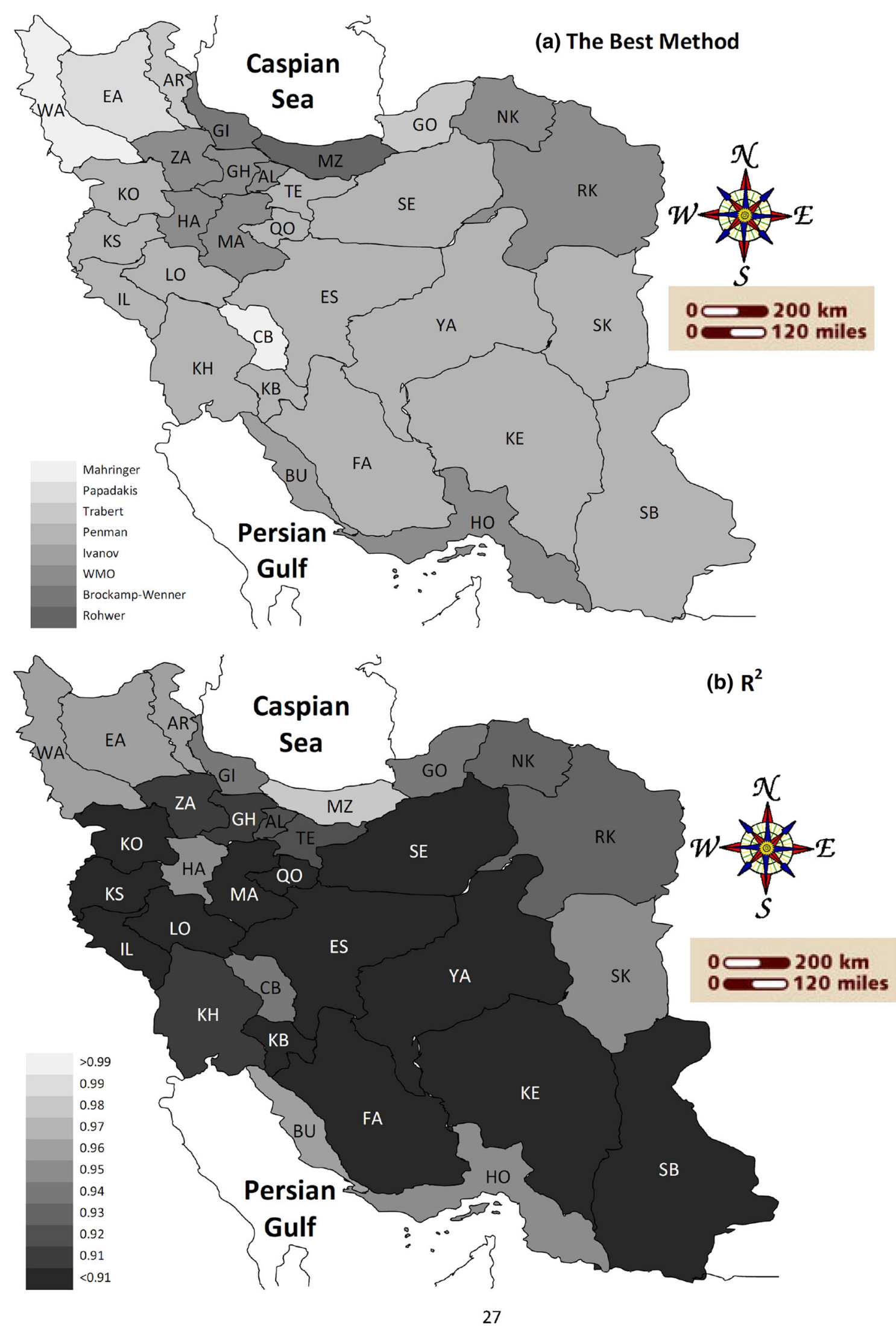

Fig. 3 The best model for each province (a) and their error after calibration (b) 
and $\left.u>3.50 \mathrm{~m} \mathrm{~s}^{-1}\right)$. However, the precision of them is different (e.g., 0.86 and 0.92 for the Albrecht and Brockamp-Wenner models, respectively). This underlines the important role of selection of the best model for a specified weather condition. Furthermore, we can see different ranges in the Ivanov, Penman, Rohwer, Papadakis, and WMO models (Table 5). This is due to different coefficient of these models that obtained for the best performance of each model (Table 4). Therefore, we can use the mass transferbased models for other regions (in other countries) based on Table 5 with respect to their errors. The best weather conditions to use mass transfer-based equations are $8-18{ }^{\circ} \mathrm{C}$ (with the exception of Ivanov), $<25.5^{\circ} \mathrm{C},<15^{\circ} \mathrm{C}$, and $>55 \%$ (with the exception of Penman) for mean, maximum, and minimum temperature, and relative humidity, respectively. The results are also useful for selecting the best model when we must apply mass transferbased models based on available data.

Comparison of the best models with their errors for each province

Figure 3 was plotted to detect the best model for each province versus its error (after calibration). According to Table 3, the best models (before calibration) for each province were selected, and their coefficients were calibrated (Table 4) to increase accuracy of estimation (Figure 3).

First, although the Penman model is the most useful model for provinces of Iran (15 provinces), but it is not suitable for four of the categories [near the Persian Gulf, near the Caspian Sea, north east of Iran, and Chaharmahal and Bakhtiari (CB)]. This confirms that the categories are reliable, and these four categories need to receive more attention due to specific weather conditions. Moreover, precision of the Penman models calibrated is less than 0.91 [with the exception of South Khorasan (SK), Tehran (TE), and $\mathrm{KH}]$. It reveals that the Penman model is a general model for estimating reference crop evapotranspiration (high application and low precision). Thus, we require other temperature, radiation, and pan evaporation-based models to estimate reference crop evapotranspiration in these 15 provinces. For instance, values of solar radiation are more than $25.0 \mathrm{MJ} \mathrm{m}^{-2}$ day $^{-1}$ for $\mathrm{SB}, \mathrm{KE}, \mathrm{FA}$, and $\mathrm{KB}$; hence, the radiation-based models may be useful for these provinces (Fooladmand 2008; Fooladmand 2011). The second favorite (selected for eight provinces) model is the WMO for which precision of estimating is less than 0.94 (with the exception of $\mathrm{HA}$ and $\mathrm{HO}$ both 0.95). However, the less favorite (selected for only one or two provinces) models including Rohwer, Papadakis, Mahringer, Brockamp-Wenner, Trabert, and Ivanov estimate reference crop evapotranspiration with $R^{2}$ more than 0.94 .
It is revealed that only if we use the mass transfer-based models for suitable (based on Table 5) and specific weather conditions, the highest precision of estimating is obtained. Meanwhile, precision of estimating is more than 0.94 for the categories I-IV (with the exception of ZA 0.91). Although the average value of weather parameters in a certain province is used for evapotranspiration estimation of that province, the evapotranspiration is a function of many weather parameters and a significant underestimation or overestimation of evapotranspiration for a province occurs for considerable variations of weather parameters. Therefore, possibility of simultaneous difference of some weather parameters with their average values which leads to a significant underestimation or overestimation of evapotranspiration for a province is poor. However, it is better to spatially distribute the weather parameters first and then to estimate the water requirements for each province for better estimation of crop water requirement of each province. In a study by Basharat and Tariq (2013), for example, they observed that the tail reaches require $33 \%$ (maximum) more water than the head reaches due to variation of rainfall in LBDC canal command in Pakistan. Also in some studies, the Penman-Monteith method shows the $10 \%$ variation when compared with the lysimeter data. Therefore, replacement of FPM model with lysimeter data can be recommended for next studies.

\section{Summary and conclusions}

In this study, 11 mass transfer-based models were used to estimate reference crop evapotranspiration in 31 provinces of Iran. In summary, the precision of estimation by mass transfer-based models is very sensitive to variations of the parameters used in each model. Thus, the coefficients of the mass transfer-based models need to be adjusted based on weather conditions of each province. According to the results, calibration is a tool required to modify mass transfer-based models the precision of estimation and to adapt the best models to weather conditions (local conditions) of each province. In the models calibrated, the Rohwer estimates reference crop evapotranspiration for $\mathrm{MZ}$ better than the other models. The provinces of Iran are divided into five categories (at least): the provinces near the Persian Gulf (KH, BU, and $\mathrm{HO}$ ), the provinces near the Caspian Sea (GI, MZ, and GO), the provinces of northeast of Iran (WA, EA, AR, and ZA), CB (due to the difference weather conditions compared to the near provinces), and the other provinces. These categories are useful for future studies over Iran. It is possible to use radiation-based models for other regions (in other countries) based on the best values of each weather parameter for best models with respect to their errors. Only if the radiation-based methods 
are used for suitable and specific weather conditions (based on weather conditions and the categories), the highest precision of estimation is obtained. The best weather conditions to use mass transfer-based equations are $8-18{ }^{\circ} \mathrm{C}$ (with the exception of Ivanov), $<25.5^{\circ} \mathrm{C},<15^{\circ} \mathrm{C}$, and $>55 \%$ (with the exception of Penman) for mean, maximum, and minimum temperature, and relative humidity, respectively. In addition, the results indicate that the Penman model is a general model for estimating reference crop evapotranspiration (high application and low precision).

Open Access This article is distributed under the terms of the Creative Commons Attribution License which permits any use, distribution, and reproduction in any medium, provided the original author(s) and the source are credited.

\section{References}

Albrecht F (1950) DieMethoden zur Bestimmung Verdunstung der natürlichen Erdoberfläche. Arch Meteor Geoph Biokl Ser B2:1-38

Allen RG, Pereira LS, Raes D, Smith M (1998) Crop evapotranspiration. guidelines for computing crop water requirements. FAO Irrigation and Drainage. Paper no. 56, FAO, Rome

Al-Sha'lan S, Salih A (1987) Evapotranspiration estimates in extremely arid areas. J Irrig Drain Eng 113:565-574

Azhar A, Perera B (2011) Evaluation of reference evapotranspiration estimation methods under southeast australian conditions. J Irrig Drain Eng 137:268-279

Banihabib ME, Valipour M, Behbahani SMR (2012) Comparison of autoregressive static and artificial dynamic neural network for the forecasting of monthly inflow of dez reservoir. J Environ Sci Technol 13:1-14. http://jest.srbiau.ac.ir/?_action= articleInfo\&article $=84$. Accessed 13 Nov 2012

Basharat M, Tariq AuR (2013) Spatial climate variability and its impact on irrigated hydrology in a canal command. Arab J Sci Eng 38:507-522

Brockamp B, Wenner H (1963) Verdunstungsmessungen auf den Steiner See bei Münster. Dt Gewa sserkundl Mitt 7:149-154

Dalton J (1802) Experimental essays on the constitution of mixed gases; on the force of steam of vapour from waters and other liquids in different temperatures, both in a torricellian vacuum and in air on evaporation and on the expansion of gases by heat. Mem Manch Lit Philos Soc 5:535-602

Fooladmand HR (2008) Evaluation of 5 methods for monthly evapotranspiration calculation in Shiraz region. J Agr Sci 13:371-379

Fooladmand HR (2011) Evaluation of some equations for estimating evapotranspiration in the south of Iran. Arch Agron Soil Sci 57:741-752

Hart QJ, Brugnach M, Temesgen B, Rueda C, Ustin SL, Frame K (2009) Daily reference evapotranspiration for California using satellite imagery and weather station measurement interpolation. Civil Eng Environ Sys 26:19-33

Irmak S, Irmak A, Allen R, Jones J (2003) Solar and net radiationbased equations to estimate reference evapotranspiration in humid climates. J Irrig Drain Eng 129:336-347

Mahdizadeh Khasraghi M, Gholami Sefidkouhi MA, Valipour M (2014) Simulation of open- and closed-end border irrigation systems using SIRMOD. Arch Agron Soil Sci. doi:10.1080/ 03650340.2014 .981163

Mahringer W (1970) Verdunstungsstudien am Neusiedler See. Arch Met Geoph Biokl Ser B18:1-20

Meyer A (1926) Ü ber einige Zusammenhänge zwischen Klima und Boden in Europa. Chemie der Erde 2:209-347

Papadakis J (1966) Climates of the world and their agricultural potentialities. Buenos Aires: published by author

Penman HC (1948) Natural evaporation from open water, bare soil and grass. Proc R Soc Lond Ser A 193:120-145

Rahimi S, Gholami Sefidkouhi MA, Raeini-Sarjaz M, Valipour M (2015) Estimation of actual evapotranspiration by using MODIS images (a case study: Tajan catchment). Arch Agron Soil Sci 61(5):695-709

Rim CS (2000) A comparison of approaches for evapotranspiration estimation. KSCE J Civil Eng 4:47-52

Rohwer C (1931) Evaporation from free water surface. USDA Tech Null 217:1-96

Romanenko VA (1961) Computation of the autumn soil moisture using a universal relationship for a large area. In: Proceedings, Ukrainian Hydrometeorological Research Institute, no. 3. Kiev

Singh VP, Xu CY (1997) Evaluation and generalization of 13 masstransfer equations for determining free water evaporation. Hydrol Process 11:311-323

Trabert W (1896) Neue Beobachtungen über Verdampfungsgeschwindigkeiten. Meteorol Z 13:261-263

Valipour M (2012a) Hydro-module determination for Vanaei Village in Eslam Abad Gharb, Iran. ARPN J Agric Biol Sci 7(12): 968-976

Valipour M (2012b) Ability of box-Jenkins models to estimate of reference potential evapotranspiration (a case study: Mehrabad Synoptic Station, Tehran, Iran). IOSR J Agric Vet Sci 1(5):1-11

Valipour M (2012c) Critical areas of Iran for agriculture water management according to the annual rainfall. Eur J Sci Res 84(4):600-608

Valipour M (2012d) Number of required observation data for rainfall forecasting according to the climate conditions. Am J Sci Res 74:79-86

Valipour M (2012e) Comparison of surface irrigation simulation models: full hydrodynamic, zero inertia, kinematic wave. J Agr Sci 4(12):68-74

Valipour M (2012f) Determining possible optimal values of required flow, nozzle diameter, and wetted area for linear traveling laterals. Int J Eng Sci 1(1):37-43. http://www.theijes.com/ papers/v1-i1/H011037043.pdf. Accessed 22 Sep 2012

Valipour M (2012g) Scrutiny of pressure loss, friction slope, inflow velocity, velocity head, and Reynolds number in center pivot. Int J Adv Sci Technol Res 2(5):703-711

Valipour M (2012h) Sprinkle and trickle irrigation system design using tapered pipes for pressure loss adjusting. J Agric Sci 4(12): $125-133$

Valipour M (2012i) Effect of drainage parameters change on amount of drain discharge in subsurface drainage systems. IOSR J Agric Vet Sci 1(4):10-18

Valipour M (2012j) A comparison between horizontal and vertical drainage systems (include pipe drainage, open ditch drainage, and pumped wells) in anisotropic soils. IOSR J Mech Civil Eng 4(1):7-12

Valipour M (2013a) Necessity of irrigated and rainfed agriculture in the world. Irrig Drain Sys Eng S9:e001.http://omicsgroup.org/ journals/necessity-of-irrigated-and-rainfed-agriculture-in-theworld-2168-9768.S9-e001.php?aid=12800. Accessed 31 Aug 2013

Valipour M (2013b) Evolution of irrigation-equipped areas as share of cultivated areas. Irrig Drain Sys Eng 2(1):e114. doi:10.4172/ 2168-9768.1000e114 
Valipour M (2013c) Need to update of irrigation and water resources information according to the progresses of agricultural knowledge. Agrotechnology S 10:e001. doi:10.4172/2168-9881.S10e001

Valipour M (2013d) Increasing irrigation efficiency by management strategies: cutback and surge irrigation. ARPN J Agric Biol Sci $8(1): 35-43$

Valipour M (2013e) Use of surface water supply index to assessing of water resources management in Colorado and Oregon, US. Adv Agric Sci Eng Res 3(2):631-640

Valipour M (2013f) Estimation of surface water supply index using snow water equivalent. Adv Agric Sci Eng Res 3(1):587-602

Valipour M (2013g) Scrutiny of inflow to the drains applicable for improvement of soil environmental conditions. In: The 1st international conference on environmental crises and its solutions, Kish Island. http://www.civilica.com/EnPaper-ICECS01ICECS01_048.html. Accessed 15 Feb 2013

Valipour M (2013h) Comparison of different drainage systems usable for solution of environmental crises in soil. In: The 1st international conference on environmental crises and its solutions, Kish Island. http://www.civilica.com/EnPaper-ICECS01ICECS01_047.html. Accessed 15 Feb 2013

Valipour M (2014a) Handbook of water engineering problems. Foster City (CA): OMICS group eBooks. http://www.esciencecentral. org/ebooks/handbook-of-water-engineering-problems/pdf/hand book-of-water-engineering-problems.pdf. Accessed 19 Jul 2014

Valipour M (2014b) Handbook of irrigation engineering problems. Foster City (CA): OMICS group eBooks. http://www. esciencecentral.org/ebooks/handbook-of-irrigation-engineeringproblems/pdf/handbook-of-irrigation-engineering-problems.pdf. Accessed 13 Aug 2014

Valipour M (2014c) Handbook of hydraulic engineering problems. Foster City (CA): OMICS group eBooks. http://www. esciencecentral.org/ebooks/handbook-of-hydraulic-engineeringproblems/pdf/handbook-of-hydraulic-engineering-problems.pdf. Accessed 11 Sep 2014

Valipour M (2014d) Future of the area equipped for irrigation. Arch Agron Soil Sci 60(12):1641-1660

Valipour M (2014e) Land use policy and agricultural water management of the previous half of century in Africa. Appl Water Sci. doi:10.1007/s13201-014-0199-1

Valipour M (2014f) A comprehensive study on irrigation management in Asia and Oceania. Arch Agron Soil Sci. doi:10.1080/ 03650340.2014 .986471

Valipour M (2014g) Irrigation status of Americas. Adv Appl Agr Sci 2(12):56-72

Valipour M (2014h) Future of agricultural water management in Americas. J Agric Res 54(2):245-268

Valipour M (2014i) Future of agricultural water management in Europe based on socioeconomic indices. Acta Adv Agric Sci 2(7): $1-18$

Valipour M (2014j) Future of agricultural water management in Africa. Arch Agron Soil Sci. doi:10.1080/03650340.2014.961433

Valipour M (2014k) Pressure on renewable water resources by irrigation to 2060. Acta Adv Agric Sci 2(8):32-42

Valipour M (2014l) Prediction of irrigated agriculture in Asia Pacific using FAO indices. Acta Adv Agric Sci 2(9):40-53

Valipour M (2014m) Temperature analysis of reference evapotranspiration models. Meteorol Appl. doi:10.1002/met.1465

Valipour M (2014n) Evaluation of radiation methods to study potential evapotranspiration of 31 provinces. Meteorol Atmos Phys. doi:10.1007/s00703-014-0351-3

Valipour M (2014o) Analysis of potential evapotranspiration using limited weather data. Appl Water Sci. doi:10.1007/s13201-0140234-2
Valipour M (2014p) Application of new mass transfer formulae for computation of evapotranspiration. J Appl Water Eng Res 2(1):33-46

Valipour M (2014q) Use of average data of 181 synoptic stations for estimation of reference crop evapotranspiration by temperaturebased methods. Water Resour Manag 28(12):4237-4255

Valipour M (2014r) Investigation of Valiantzas' evapotranspiration equation in Iran. Theor Appl Climatol. doi:10.1007/s00704-014$1240-\mathrm{x}$

Valipour M (2014s) Assessment of different equations to estimate potential evapotranspiration versus FAO Penman-Monteith method. Acta Adv Agric Sci 2(11):14-27

Valipour M (2014t) Comparative evaluation of radiation-based methods for estimation of potential evapotranspiration. J Hydrol Eng. doi:10.1061/(ASCE)HE.1943-5584.0001066

Valipour M (2014u) Handbook of hydrologic engineering problems. Foster City (CA): OMICS group eBooks. http://www. esciencecentral.org/ebooks/handbook-of-hydrologic-engineeringproblems/pdf/handbook-of-hydrologic-engineering-problems.pdf. Accessed 26 Jul 2014

Valipour M (2014v) Handbook of drainage engineering problems. Foster City (CA): OMICS Group eBooks. http://www. esciencecentral.org/ebooks/handbook-of-drainage-engineeringproblems/pdf/handbook-of-drainage-engineering-problems.pdf

Valipour M (2014w) Drainage, waterlogging, and salinity. Arch Agron Soil Sci 60(12):1625-1640

Valipour M (2014x) Handbook of environmental engineering problems. Foster City (CA): OMICS group eBooks. http:// www.esciencecentral.org/ebooks/handbook-of-environmentalengineering-problems/pdf/handbook-of-environmental-engineeringproblems.pdf. Accessed 5 Mar 2014

Valipour M (2014y) Variations of irrigated agriculture indicators in different continents from 1962 to 2011. Adv Water Sci Technol $1(1): 1-14$

Valipour M (2015a) Long-term runoff study using SARIMA and ARIMA models in the US. Meteorol Appl. doi:10.1002/met. 1491

Valipour M (2015b) Study of different climatic conditions to assess the role of solar radiation in reference crop evapotranspiration equations. Arch Agron Soil Sci 61(5):679-694

Valipour M (2015c) Importance of solar radiation, temperature, relative humidity, and wind speed for calculation of reference evapotranspiration. Arch Agron Soil Sci 61(2):239-255

Valipour M, Eslamian S (2014) Analysis of potential evapotranspiration using 11 modified temperature-based models. Int J Hydrol Sci Technol 4(3):192-207

Valipour M, Montazar AA (2012a) Optimize of all effective infiltration parameters in furrow irrigation using visual basic and genetic algorithm programming. Aust J Basic Appl Sci 6(6): 132-137

Valipour M, Montazar AA (2012b) Sensitive analysis of optimized infiltration parameters in SWDC model. Adv Environ Biol 6(9):2574-2581

Valipour M, Montazar AA (2012c) An evaluation of SWDC and WINSRFR models to optimize of infiltration parameters in furrow irrigation. Am J Sci Res 69:128-142

Valipour M, Banihabib ME, Behbahani SMR (2012a) Parameters estimate of autoregressive moving average and autoregressive integrated moving average models and compare their ability for inflow forecasting. J Math Stat 8(3):330-338

Valipour M, Banihabib ME, Behbahani SMR (2012b) Monthly inflow forecasting using autoregressive artificial neural network. J Appl Sci 12(20):2139-2147

Valipour M, Mousavi SM, Valipour R, Rezaei E (2012c) SHCP: soil heat calculator program. IOSR J Appl Phys 2(3):44-50 
Valipour M, Mousavi SM, Valipour R, Rezaei E (2012d) Air, water, and soil pollution study in industrial units using environmental flow diagram. J Basic Appl Sci Res 2(12):12365-12372

Valipour M, Mousavi SM, Valipour R, Rezaei E (2013a) Deal with environmental challenges in civil and energy engineering projects using a new technology. J Civil Environ Eng 3(1):127

Valipour M, Mousavi SM, Valipour R, Rezaei E (2013b) A new approach for environmental crises and its solutions by computer modeling. In: The 1st international conference on environmental crises and its solutions, Kish Island. http://www.civilica.com/ EnPaper-ICECS01_005.html

Valipour M, Banihabib ME, Behbahani SMR (2013c) Comparison of the ARMA, ARIMA, and the autoregressive artificial neural network models in forecasting the monthly inflow of Dez dam reservoir. J Hydrol 476:433-441

Valipour M, Ziatabar Ahmadi M, Raeini-Sarjaz M, Gholami Sefidkouhi MA, Shahnazari A, Fazlola R, Darzi-Naftchali A (2015a) Agricultural water management in the world during past half century. Arch Agron Soil Sci 61(5):657-678
Valipour M, Gholami Sefidkouhi MA, Eslamian S (2015) Surface irrigation simulation models: a review. Int J Hydrol Sci Technol (Accepted)

World Meteorological Organization (WMO) (1966) Measurement and estimation of evaporation and evapotranspiration. Tech Pap (CIMO-Rep) 83. Genf

Xu CY, Chen D (2005) Comparison of seven models for estimation of evapotranspiration and groundwater recharge using lysimeter measurement data in Germany. Hydrol Process 19:3717-3734

Xu CY, Singh VP (2000) Evaluation and generalization of radiationbased methods for calculating evaporation. Hydrol Process 14(2):339-349

Xu CY, Singh VP (2002) Cross comparison of empirical equations for calculating potential evapotranspiration with data from Switzerland. Water Resour Manag 16(3):197-219

Zhai L, Feng Q, Li Q, Xu C (2010) Comparison and modification of equations for calculating evapotranspiration (ET) with data from Gansu Province, Northwest China. Irrig Drain 59:477-490 